\title{
Talent Retention Model for Millennials Based on Engagement Drivers Case study: LQ45 Company
}

\author{
Lindawati Kartika $^{1}$, Muh Panji Sukarno ${ }^{2}$, Fransiskus Suryopranoto ${ }^{3}$,Hendry ${ }^{4}$, \\ FanyRachmaditya $^{5}$ \\ Faculty of Economic and Business, University of Indonesia, Indonesia $a^{1,2,3,4,5}$
}

muh.panji@ui.ac.id²

\begin{abstract}
Millennial employees have psychic characteristics that are different from other generations. Millennial employees have the lowest engagement rates compared to Generation X and Baby Boomers (Hewitt 2016). The purpose of this study is to analyze the main engagement generation of Millennial employees in LQ 45 companies, analyze the factors of engagement of Millennial employees who work for LQ 45 companies and formulate engagement enhancement strategies that are in line with the characteristics of Millennial employees. The data used in this study are primary data obtained through questionnaires and secondary data from LQ 45 Company Samples, namely PT Astra International, Unilever, Elnusa. PT and PT Wijaya Karya. The method used in this study is descriptive analysis, factor analysis and Tree Diagram. The results showed that work life balance is the main engagement driver according to the perception of Millennial, autonomous Generation employees and career opportunity is the main engagement driver according to expert perceptions. Factor analysis forms six factors of engagement, namely organization, compensation and benefits, the work, team work, pride, and performance. The model for increasing the engagement of Millennial employees is presented in a Tree Diagram with the Co-Auto Balance Gamification formula.
\end{abstract}

Keywords:Engagement Driver, LQ 45, Milenial, Strategy, Tree Diagram Model

\section{Introduction}

Employee engagement is still one of the most strategic issues in the field of corporate human resources (HR) until 2018. Research from Hewitt [1] states that the level of engagement in a company has significant financial implications. Consistently through a statistical approach, there is a relationship between the level of engagement that is high and the financial performance of a company. Every 5 (five) percent increase in engagement level will increase revenue growth by 3 (three) percent. However, making employees engaged is one of the challenges for the company because each employee has a different level of engagement. Based on research conducted by 
Hewitt [2] there is a difference in the level of employee engagement based on generation as shown in Figure 1.

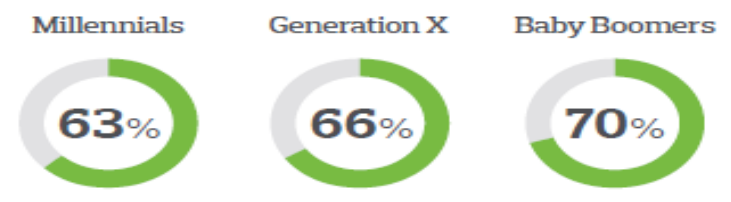

Fig. 1. Segment level engagement based on generation [2]

The engagement level of Millennial employees is the lowest compared to the Baby Boomers and Generation X generations. This fact needs special attention because in 2020 this generation is projected to be the largest generation in the world of work. Globally, this generation is projected to reach a portion of 50 percent in the world of work because in that year the majority of Millennial has entered the productive age. Millennials have essentially the same needs as other generations, but Millennials have unique needs shaped by technology, constant feedback (such as social media), changes in the composition of the workforce and economic volatility [2]

The proportion of Millennials in each country is different. Indonesia's workforce in 2016 has been filled by three different generations, namely Baby Boomers, Generation X, and Millennial. The proportion of Millennials to the national workforce is shown in Table 1. The data in Table 1 if calculated shows that the number of Millennials who work has reached 46847228 people, while the total workforce has reached 120647697 so the percentage of Millennial work has reached 38.83 percent. Generation X (age range 35 to 54 years in the table) is still slightly higher in the percentage of 45.30 percent, while Baby Boomers are only 15.87 percent. This calculation uses a 2016 database, meaning that in 2018 the number of Millennials in the world of work has increased by more than 38.83 percent.

Table 1. Indonesian labor force according to age group 2016

\begin{tabular}{cccc}
\hline Age Group & Working Age that Works & Proportion $(\%)$ & Remarks $^{*}$ \\
\hline $15-19$ & 4873611 & \\
$20-24$ & 12295397 & 38.83 & Milenial \\
$25-29$ & 14557279 & & \\
$30-34$ & 15120941 & & \\
$35-39$ & 15452579 & Generation X \\
$40-44$ & 14748920 & 45.30 & \\
$45-49$ & 13374073 & & Generation Baby \\
$50-54$ & 11077423 & Boomers \\
$55-59$ & 8259948 & \\
$60+$ & 10887526 & 15.87 & \\
\hline Total & 120647 697 & \\
\hline \multicolumn{4}{c}{ Source: Badan Pusat Statistik (2016) } \\
\hline
\end{tabular}

The increasing dominance of the Millennial in the world of work in Indonesia with its special characteristics has made the formulation of appropriate human capital strategies very necessary so that the potential of this generation can be utilized optimally. Increasing the number of Millennials in the world of work requires special attention by the human resource management, including in terms of engagement, because of the fact that Millennials have the lowest level of engagement 
compared to other generations. This fact must be accommodated by the company by formulating a strategy for increasing engagement for the Millennial. Millennial preferences need to be further investigated according to the need for advancing corporate human resources in various industrial sectors in Indonesia.

The industrial sector that contributes to the national Gross Domestic Product (GDP) includes the oil and gas and non-oil and gas sectors. The non-oil sector business sector is the biggest contributor to Indonesia's GDP. Non-oil and gas GDP reaches 89.97 percent of total GDP in 2017 [3]The business sector of the non-oil and gas sector includes industries in LQ 45. The LQ 45 industry can come from all sectors of non-oil and gas business as long as the company engaged in the business field meets the characteristics and has a fast track program for Fresh graduates.

Millennials are often associated with the motto we hired to leave. Based on the Millennial survey conducted by Deloitte [3] stated that 62 percent of Millennial employees in Indonesia already have the confidence to leave their company before 2020. The conditions in which Millennial employees have plans to leave the company make it difficult for employees of the Millennial to be engaged in their company. Based on these considerations, research is needed that is related to the Talent Retention model based on employee engagement of Millennial employees in LQ 45-based companies so that they can be utilized to minimize the tendency of Millennial employees to move companies.

The problems can be formulated as follows:

1. What is the main engagement driver for Millennial employees in LQ 45 companies?

2. What are the factors of engagement of Millennial employees in LQ 45 companies that can make them engaged with the company?

3. What is the right management strategy for Millennial employees in LQ 45 companies so that they can be engaged with the company?

This research was conducted on Millennial employees who work in companies in Companies listed on LQ 45. The research focused on analyzing Millennial employee engagement drivers at LQ 45 companies. The theory of engagement used was a theory from Hewitt who introduced The Aeon Hewitt Engagement Model [2] and the generation theory used is according to Howe and Strauss [4]

\section{Literature Review}

Previous research related to Millennial and employee engagement has been carried out. In 2014 Aguilar conducted a research related to Millennial employee motivational drivers. In [2] Hewitt conducted research related to the trend of employee engagement and Simbolon has also conducted research related to Quality of Work Life Generation X and Y in the same year. In addition, Fountain [8] has also conducted research related to the relationship between the level of engagement, engagement drivers, and bullying behavior. Research related to engagement and generation has been carried out by Amuzu in 2017. The recapitulation of previous research is shown in Table 2.

Table 2. Recapitulation of the results of previous studies

\begin{tabular}{ccccccc}
\hline No & Title & Year & Writer & Method & Result & Source \\
\hline 1 & Engaging the & 2017 & Cecilia S. & Multivariate & There is no & Northcentr \\
& Workforce : & & Amuzu & Analysis of \\
difference in & Variance \\
Baby Boomers, & & & engagement & al \\
Generation Xers & & & (Manova) & drivers between & $\begin{array}{c}\text { University, } \\
\text { Proquest }\end{array}$ \\
\hline
\end{tabular}




\begin{tabular}{|c|c|c|c|c|c|c|}
\hline & and Millennials & & & & $\begin{array}{l}\text { Baby Boomers, } \\
\text { Generation X, and } \\
\text { Millennials. }\end{array}$ & $\begin{array}{c}\text { Dissertatio } \\
\mathrm{n} \\
\text { Publishing }\end{array}$ \\
\hline 2 & $\begin{array}{l}2015 \text { Trends in } \\
\text { Global } \\
\text { Employee } \\
\text { Engagement }\end{array}$ & 2016 & $\begin{array}{c}\text { Aon } \\
\text { Hewitt }\end{array}$ & $\begin{array}{c}\text { Descriptive } \\
\text { Analysis }\end{array}$ & $\begin{array}{l}\text { The main } \\
\text { engagement } \\
\text { factors of } \\
\text { Millennial } \\
\text { employees are } \\
\text { career } \\
\text { opportunities, } \\
\text { salary (pay), } \\
\text { company } \\
\text { reputation } \\
\text { (organization } \\
\text { reputation), brand } \\
\text { alignment and } \\
\text { recognition } \\
\text { (recognition) }\end{array}$ & $\begin{array}{c}\text { Aon } \\
\text { Hewitt } \\
\text { Report }\end{array}$ \\
\hline 3 & $\begin{array}{c}\text { Analysis of } \\
\text { Quality of Work } \\
\text { Life in } \\
\text { Generation X } \\
\text { and Y Alumni of } \\
\text { the Faculty of } \\
\text { Economics and } \\
\text { Management of } \\
\text { IPB }\end{array}$ & 2016 & $\begin{array}{l}\text { Dwi } \\
\text { Astrid } \\
\text { Avianti } \\
\text { Simbolon }\end{array}$ & $\begin{array}{l}\text { Descriptive } \\
\text { Analysis, } \\
\text { Pairwise } \\
\text { Comparison, } \\
\text { The House } \\
\text { Model }\end{array}$ & $\begin{array}{l}\text { QWL priority } \\
\text { factors in } \\
\text { Generation X are } \\
\text { workplace safety, } \\
\text { compensation and } \\
\text { conflict } \\
\text { resolution. The } \\
\text { QWL priority } \\
\text { factor in } \\
\text { Generation Y is } \\
\text { compensation, } \\
\text { career } \\
\text { development, and } \\
\text { pride. }\end{array}$ & $\begin{array}{c}\text { Essayof } \\
\text { IPB } \\
\text { Bachelor } \\
\text { Degree of } \\
\text { Manageme } \\
\text { nt }\end{array}$ \\
\hline 4 & $\begin{array}{l}\text { Relationship } \\
\text { among Work } \\
\text { Engagement, } \\
\text { Drivers of } \\
\text { Engagement, } \\
\text { and Bullying } \\
\text { Acts in } \\
\text { Registered } \\
\text { Nurses Working } \\
\text { in Hospital } \\
\text { Settings }\end{array}$ & 2016 & $\begin{array}{l}\text { Donna } \\
\text { M. } \\
\text { Fountain }\end{array}$ & $\begin{array}{l}\text { Descriptive } \\
\text { Analysis, } \\
\text { Correlation } \\
\text { Analysis }\end{array}$ & $\begin{array}{l}\text { All psychic } \\
\text { engagement } \\
\text { drivers increase } \\
\text { employee } \\
\text { engagement, }\end{array}$ & $\begin{array}{l}\text { Rutgers } \\
\text { The State } \\
\text { University } \\
\text { of New } \\
\text { Jersey }\end{array}$ \\
\hline 5 & $\begin{array}{c}\text { Identification of } \\
\text { Motivational } \\
\text { Drivers of } \\
\text { Generation Y } \\
\text { Employees }\end{array}$ & 2014 & $\begin{array}{l}\text { Camille } \\
\text { M. } \\
\text { Aguilar }\end{array}$ & $\begin{array}{c}\text { Descriptive } \\
\text { Analysis }\end{array}$ & $\begin{array}{l}\text { The main } \\
\text { motivation factor } \\
\text { for Millennial } \\
\text { employees is in } \\
\text { the category of }\end{array}$ & $\begin{array}{c}\text { San Jose } \\
\text { State } \\
\text { University, } \\
\text { Proquest } \\
\text { Dissertatio }\end{array}$ \\
\hline
\end{tabular}




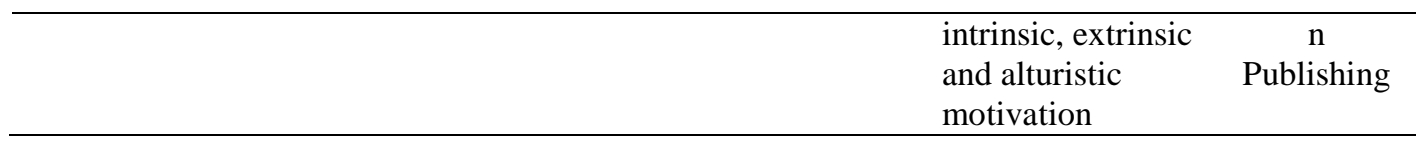

Source : Literature Studies (Processed 2018)

\section{Method}

\section{a. Framework}

Millennial employees have the lowest engagement rates compared to baby boomers and Generation X. Besides low engagement rates, the proportion of the Millennial workforce has reached 38.83 percent in 2016. This means that in 2018 the proportion will increase. The increase in the proportion of Millennials in the workforce needs special attention because of the low level of engagement. The level of engagement of Millennial employees must be considered by all types of companies, including LQ 45 companies.

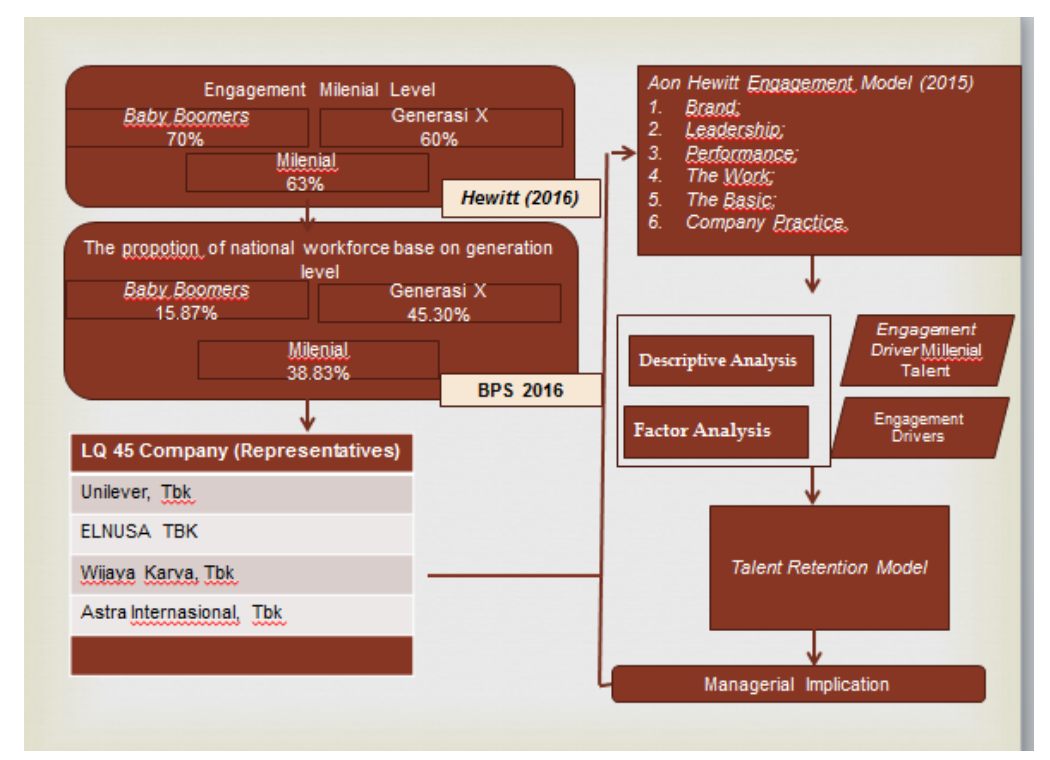

Fig. 2. Research Framework

This research takes the object of Millennial employees who work for LQ 45 companies in Indonesia. The selection of research locations nationally was determined deliberately by considering that the research sample was able to represent the talent who entered through the fast track process in the LQ 45 company. The study was conducted from November 2018 to December 2018. The data used in this study were primary data and secondary data that were qualitative and quantitative. Primary data is in the form of data obtained from respondent answers to Millennial employees and expert respondent answers. Secondary data in the form of company documents, internet data, the Central Statistics Agency, and literature studies for theoretical references that are in accordance with the research topic.

Population is a generalization area consisting of: objects / subjects that have certain qualities and characteristics determined by researchers to be studied and then conclusions drawn [9] The population of this study is Millennial employees who work for LQ 45 companies. The population data from this study are not specifically known. However, to ascertain the specific sample size, in 
this study the determination was carried out using the formula Lemmeshow [10] where this formula is suitable for the exact number of populations that are not known as follows.

$n=\frac{Z^{2} x P(1-P)}{\mathrm{d}^{2}}$

Remarks :

$\mathrm{n} \quad=$ Number of sample

$\mathrm{P} \quad=$ Estimation $(0.5)$

$\mathrm{Z}^{2} \quad=\mathrm{z}$ scorein confidence level $90 \%=1.645$

$\mathrm{d}^{2} \quad=$ Sampling error $(10 \%)$

Based on these opinions, the sample size in this study can be determined as follows

$n=67.65 \approx 70$

$$
n=\frac{1.645^{2} \times 0.5(1-0.5)}{0.1^{2}}
$$

The calculation resulted in a sample size of 67.65 people or rounded up to 70 people so that this study must at least get as many as 70 respondents. Sampling in this study using nonprobability sampling method with snowball sampling technique and purposive sampling. The snowball sampling technique is a technique in which a sample of researchers comes from a small group that is relevant to the research question and the sample then invites other participants who have relevant characteristics to become respondents. The purposive sampling technique is sampling by selecting individuals based on their relevance to the research question [11]

The snowball sampling technique is done by sending a questionnaire link to employees who meet the criteria of this study that are sent freely via email and social media. Online questionnaires are created using Google Form. The online questionnaire is aimed at all Millennial employees who work for LQ 45 companies in 2018. The questionnaire instrument uses a six-point differential semantic scale that measures perceptions of the importance of each engagement factor for respondents. Specifically, a score of one indicates that the factor is not very important, the score of six is very important, and the score between one and six is not labeled. The number of response options as many as six was chosen based on the research findings of the optimal number of response categories related to validity, reliability, and ease of use [12] The response format does not provide a neutral choice (middle response) to avoid the tendency of respondents to choose the neutral value so that the resulting answer can give a picture that fits the scale of relative importance perceived by the respondent without any biased answers.

The total sample of Millennial employees obtained in this study amounted to 131 people and fulfilled the requirements for the minimum number of samples. The distribution of respondents from this study based on the sub-sector where respondents work can be seen in Table 3.

Table 3. Recapitulation of the distribution of respondents

\begin{tabular}{lcc}
\hline \multicolumn{1}{c}{ Subsector } & Number & Percentage $(\%)$ \\
\hline Astra Internasional & 116 & 88.50 \\
Unilever & 4 & 3.10 \\
Elnusa & 3 & 2.30 \\
Wijaya Karya & 2 & 1.50 \\
\hline Total & 131 & 100 \\
\hline
\end{tabular}


Source : Data processed (2018)

In addition, purposive sampling technique is done by contacting experts in the field of human resources both from academics, professionals, and consultants in the field of human resources through e-mail and personal contact. Experts who stated they were willing to become respondents were then sent special expert questionnaires. The first expert respondent in this study worked as a lecturer at the Faculty of Economics and Business, University of Indonesia; the second expert worked as a human resource consultant at a consulting company consisting of HR experts where he was the founder of the company and also worked as general manager of HRD at a company located in Tangerang; the third expert works as human capital analytics in a manufacturing company located in North Jakarta; The fourth expert works as a human capital director at a health drink producer company located in Jabodetabek. The fifth expert works as vice president of human resources at a mining company located in Jakarta. The questionnaire was presented with open questions "How do you think about the processing strategies of Millennials to be engaged with the company"

\section{b. Data Processing and Analysis Method}

Test Validity shows the extent to which a measuring device can measure what is measured. The validity test aims to determine the validity level of the questionnaire. Validity testing is done by testing the measuring instrument with a sample of at least 30 people [13]. Based on the validity test conducted, it was found that all the questions in this research questionnaire were declared valid with $r$ counts greater than $r$ table $(\mathrm{N}=131)$. Reliability Test is a procedure to determine the extent to which measurement results remain consistent, if measurements are taken twice or more for the same symptoms by using the same measuring device [14] Reliability test states that the research instrument is reliable if the alpha count value is greater than the r-table value. The alpha coefficient assumes that if the a-cronbach value is greater than 0.60 (a-Cronbach theory) then the questionnaire can be said to be reliable. Reliability testing is carried out on data that has been collected from questionnaires distributed online to respondents. Reliability testing uses the Cronbach's Alpha technique with the help of Software Statistics Product and Service Solution (SPSS) 20.0. Based on the reliability test conducted, it was found that the Cronbach's Alpha value was 0.89 (greater than 0.60), meaning that the research instruments used were reliable.

\section{c. Decriptive Analysis}

This study uses a score of six points converted into percentages, where the score of six is a positive pole $(100 \%)$, and the score of one is a negative pole $(0 \%)$. A numerical linear scale can be made with the following formula.

$R S=\frac{m-n}{b}$

Remarks :

RS = scale range

$\mathrm{m} \quad=$ highest score in range

$\mathrm{n} \quad=$ lowest score in range

$\mathrm{b} \quad=$ number of class or category made

Based on these equations, the measurement results through a semantic differential scale, where $m=100$ percent, $n=0$ percent, into six classes $(b=6)$, then the calculation is: 


$$
R S=\frac{100 \%-0 \%}{6}=16,67 \%
$$

The standard for the six categories of classes formed is:
$0.00 \%-16.67 \%=$ very unimportant
$16.67 \%<$ modus $\leq 33.34 \%=$ unimportant
$33.34 \%<$ modus $\leq 50.01 \%$ = slightly unimportant
$50.01 \%<$ modus $\leq 66.68 \%$ = slightly important
$66.68 \%<$ modus $\leq 83.35 \%=$ important
$83.35 \%<$ modus $\leq 100.00 \%=$ very important

Data processing for descriptive analysis was carried out using the help of Microsoft Office Excel 2013 Software and SPSS 20.0 for Windows software. Descriptive analysis conducted produces output in the form of information about the importance of each of the Millennial employee engagement drivers based on the mode by utilizing the scale range of the six class categories formed. In addition, descriptive analysis of expert answers resulted in priority driver engagement according to experts presented in the form of a venn diagram to see the similarity of perceptions of expert respondents.

\section{Result and Discussion}

Talent respondents who filled out questionnaires as many as 131 employees with bachelordegree, the dominant tenure of 105 people less than 2 years, and work locations in DKI Jakarta, and were dominated by men. Descriptive analysis results have been carried out to measure the relative importance of engagement drivers of Millennial employees who work for LQ 45 Sample companies Engagement drivers according to Hewitt's theory [1] consist of six groups which are then divided into 25 questions representing six groups of engagement drivers. The response of each respondent indicates the perception of Millennial employees for each engagement driver as on table 4.

Table 4. Response of each respondent

Company Name

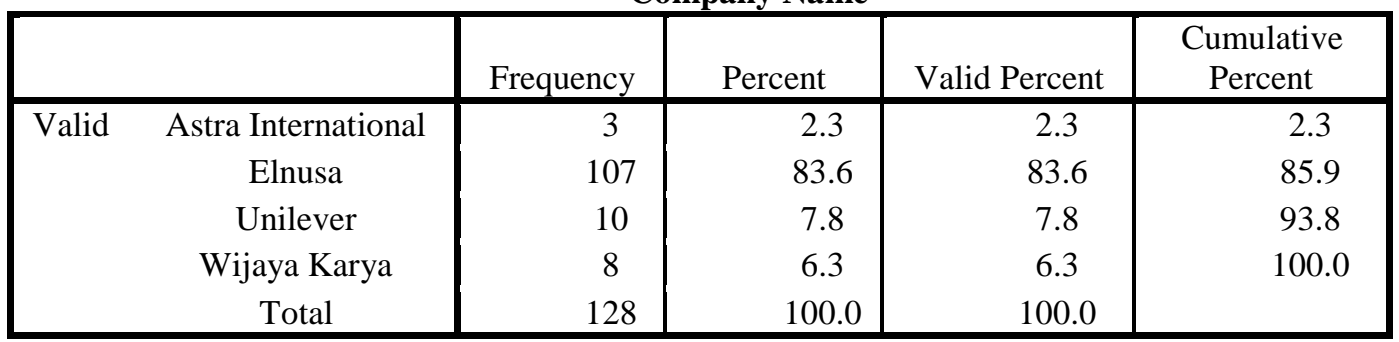

Company's Subsector

\begin{tabular}{|lc|c|c|c|c|}
\hline & & Frequency & Percent & Valid Percent & $\begin{array}{c}\text { Cumulative } \\
\text { Percent }\end{array}$ \\
\hline Valid & Automotive & 3 & 2.3 & 2.3 & 2.3 \\
& Construction & 8 & 6.3 & 6.3 & 8.6 \\
& Consumer Goods & 10 & 7.8 & 7.8 & 16.4 \\
& Oil And Gas & 107 & 83.6 & 83.6 & 100.0
\end{tabular}




\begin{tabular}{|c|c|c|c|c|c|}
\hline & Total & 128 & 100.0 & 100.0 & \\
\hline & \multicolumn{5}{|c|}{ Location } \\
\hline & & Frequency & Percent & Valid Percent & $\begin{array}{c}\text { Cumulative } \\
\text { Percent }\end{array}$ \\
\hline \multirow[t]{6}{*}{ Valid } & Bekasi & 5 & 3.9 & 3.9 & 3.9 \\
\hline & Bogor & 3 & 2.3 & 2.3 & 6.3 \\
\hline & Depok & 2 & 1.6 & 1.6 & 7.8 \\
\hline & DKI Jakarta & 111 & 86.7 & 86.7 & 94.5 \\
\hline & Tangerang Selatan & 7 & 5.5 & 5.5 & 100.0 \\
\hline & Total & 128 & 100.0 & 100.0 & \\
\hline
\end{tabular}

\section{Gender}

\begin{tabular}{|cc|r|r|r|r|}
\hline & & & & Cumulative \\
& & Frequency & Percent & Valid Percent & Percent \\
\hline Valid & Male & 71 & 55.5 & 55.5 & 55.5 \\
& Female & 57 & 44.5 & 44.5 & 100.0 \\
& Total & 128 & 100.0 & 100.0 & \\
\hline
\end{tabular}

\section{Education}

\begin{tabular}{|cc|c|c|c|c|}
\hline & & & Cumulative \\
Valid & D1 & 1 & Percent & Valid Percent & $\begin{array}{c}\text { Percent } \\
\end{array}$ \\
& D3 & 1 & .8 & .8 & .8 \\
S1 & 116 & .8 & .8 & 1.6 \\
S2 & 9 & 7.0 .6 & 90.6 & 92.2 \\
S3 & 1 & .8 & 7.0 & 99.2 \\
Total & 128 & 100.0 & .8 & 100.0 \\
\hline
\end{tabular}

\section{Status}

\begin{tabular}{|c|c|c|c|c|c|}
\hline & & Frequency & Percent & Valid Percent & $\begin{array}{c}\text { Cumulative } \\
\text { Percent }\end{array}$ \\
\hline \multirow[t]{3}{*}{ Valid } & Married & 26 & 20.3 & 20.3 & 20.3 \\
\hline & Single & 102 & 79.7 & 79.7 & 100.0 \\
\hline & Total & 128 & 100.0 & 100.0 & \\
\hline
\end{tabular}

Working Experience

\begin{tabular}{|rc|r|r|r|r|}
\hline & & & Cumulative \\
& Frequency & Percent & Valid Percent & \begin{tabular}{c} 
Percent \\
\hline Valid
\end{tabular} \\
& 1 1 t tahun & 30 & 23.4 & 23.4 & 23.4 \\
& 19 & 61.7 & 61.7 & 85.2
\end{tabular}




\begin{tabular}{c|c|c|c|c|}
\hline$>2-3$ Tahun & 6 & 4.7 & 4.7 & 89.8 \\
$>3-4$ Tahun & 4 & 3.1 & 3.1 & 93.0 \\
$>4-5$ Tahun & 7 & 5.5 & 5.5 & 98.4 \\
$>5$ Tahun & 2 & 1.6 & 1.6 & 100.0 \\
Total & 128 & 100.0 & 100.0 & \\
\hline
\end{tabular}

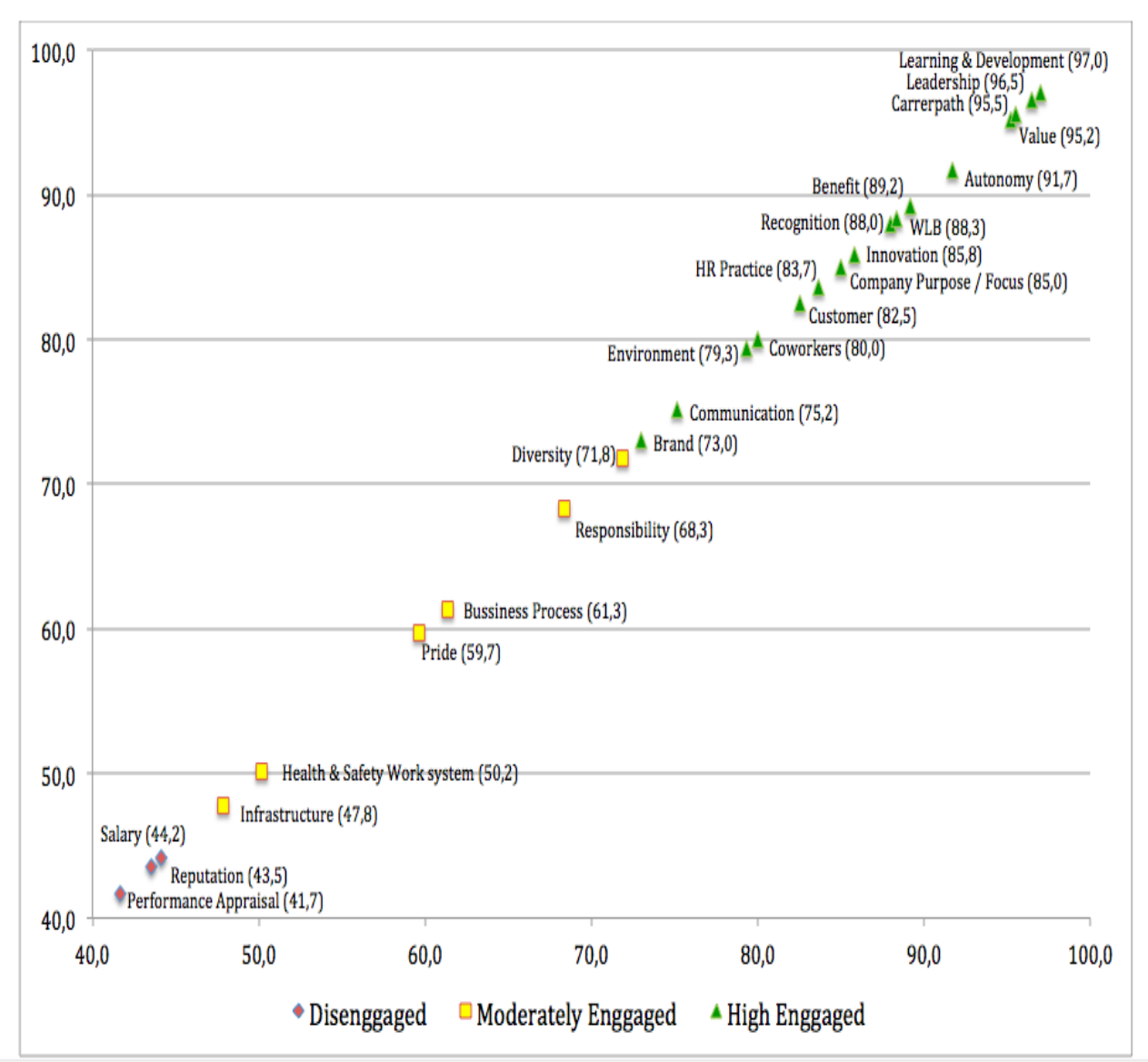

Fig. 3. Results of descriptive analysis of employee perceptions

Source: Processed data (2018)

The results of the analysis show that the majority of engagement drivers presented in this study are considered very important by Millennial employees. Engagement drivers that are considered to be the most important are work life balance with a mode value of 98.50 percent. This result is supported by Duchscher's [17] study which states that Millennials tend to give a higher level of importance to work life balance than previous generations, describing them as a generation that actively strives to achieve and maintain a harmonious balance between home and work life.

Diversity is an engagement driver that is relatively considered less important by Millennial employees who work for LQ 45 companies with 55.80 percent mode value. Diversity referred to in this study is related to diversity in the work environment or work group, such as diversity of sexes, 
age, or diversity of core competencies possessed by each individual in the work group. Respondents in this study consider that diversity is not the priority to make them engaged with their company.

\section{a. Engagement Priority Driver for Millennial Employees according to Experts}

Five experts have contributed to become respondents in this study. These experts come from human resource academics, human resource consultants, and human resource professionals. Open questions about the strategy of increasing the engagement of Millennial employees have been provided with diverse responses. The results of expert respondent answers are presented in the form of visualization of the Venn Diagram as follows.

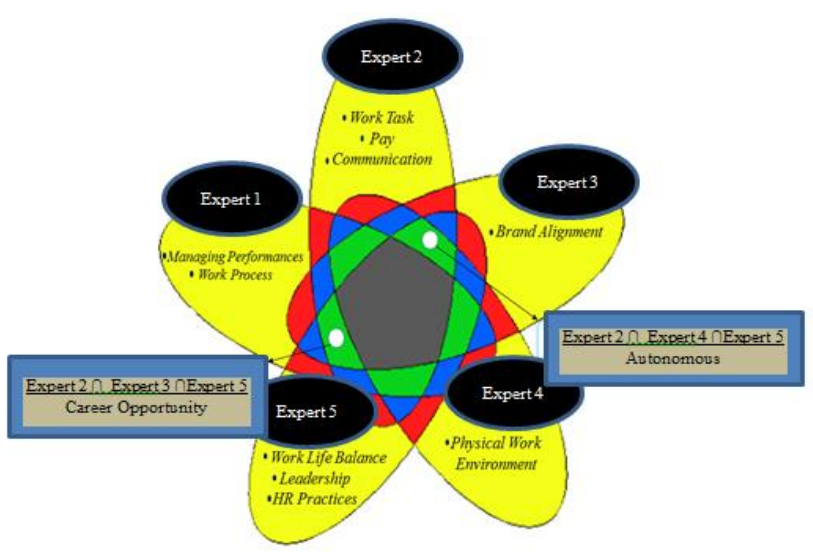

Fig. 4. Expert perception Venn diagram Source: Processed data (2018)

Figure 4 shows that autonomy is engagement driver which is considered a priority by expert two, expert four, and expert five. It can be concluded that autonomy is the most important engagement driver for Millennial employees according to experts. Millennial employees prefer to work for companies that already have a clear system that gives them the opportunity to do their best in achieving their goals according to their potential. These characters make autonomy important to them according to expert perceptions. In addition, career opportunity can also be interpreted as the main engagement driver because it is considered a priority by expert two, expert three, and expert five. Experts in this study stated that career path and position name are one of the most important things for Millennial employees. They are people who want to be instant, want to be considered capable, want to be considered great, compare with each other because of the internet of things, don't really like working hard and need recognition. This character makes career opportunity very important for Millennial employees according to expert perceptions.

The company really needs creativity as the main capital in running a business. Millennial employees need greater autonomy in doing their jobs according to their personal creativity and initiative. Therefore, Millennial employees must be given space to develop their potential and independence in carrying out their work duties. In addition to autonomy at work, Millennial employees who work for LQ 45 companies also need clear career growth so companies need to pay attention to career opportunities for Millennial employees. Companies can implement functional career paths in addition to structural career paths to accommodate those needs. 


\section{b. Factor Analysis of Engagement of Millennial Employees}

Testing the correlation between variables in the perception of Millennial employees is carried out using the Barlett test of sphericity method and Kaiser-Meyer-Olkin Measure of Sampling Adequacy (KMO) measurements. Value of KMO and Barlett's Test, where the results of factor analysis show KMO-MSA value of 0.81 (greater than 0.5 ) with a significance of 0.000 (smaller than 0.05). This shows that the existing variables and samples have met the requirements for further analysis, so it does not need to be iterated. The next step is to extract the variables so that fewer factors will be formed. One of the results obtained from the extraction of variables is the value of communalities. The value of communalities is the number of variants of an initial variable that can be explained by existing factors. The greater the value of communalities of a variable, the more closely related to the factors formed.

The next process is to analyze component matrix, which is the stage that shows the distribution of each variable on the six factors formed. Values that indicate the magnitude of a variable with respect to each of the new factors formed can be seen in the component matrix table, namely the loading value. Factor rotation will increase the value of the variable loading which initially is already large and reduces the loading value which was initially small. The eigenvalue and loading values that meet the requirements (eigenvalue> 1.1 and loading $>0.5$ ) in each of the factors formed can be seen in Table 5 .

Table 5. The main factors resulting from factor analysis

\begin{tabular}{|c|c|c|c|c|}
\hline Factor & Eigenvalue & Variance $(\%)$ & Variable & Loading \\
\hline Work & 6.25 & 24.99 & 5. Work Life Balance & 0.877 \\
\hline \multirow[t]{6}{*}{ Atmosphere } & & & 6. Benefit & 0.748 \\
\hline & & & 14. Environment & 0.746 \\
\hline & & & 12. Salary & 0.554 \\
\hline & & & 23. HR Practice & 0.489 \\
\hline & & & 25. Enabling Infrastructure & 0.470 \\
\hline & & & 16. Health and safety work system & 0.319 \\
\hline \multirow[t]{6}{*}{ Vigor } & 2.22 & 8.88 & 20. Career Path & 0.807 \\
\hline & & & 9. Learning and Development & 0.801 \\
\hline & & & 3. Innovation & 0.521 \\
\hline & & & 15. Autonomy & 0.464 \\
\hline & & & 4. Recognition & 0.450 \\
\hline & & & 2. Brand & 0.407 \\
\hline \multirow[t]{4}{*}{ Team Work } & 2.04 & 8.15 & 1. Leadership & 0.664 \\
\hline & & & 10. Managing Performance & 0.599 \\
\hline & & & 19. Diversity & 0.448 \\
\hline & & & 8. Coworkers & 0.433 \\
\hline \multirow[t]{4}{*}{ Dedication } & 1.35 & 5.43 & 18. Responsibility & 0.730 \\
\hline & & & 24. Value & 0.690 \\
\hline & & & 7. Communication & 0.583 \\
\hline & & & 13. Bussiness Process & 0.502 \\
\hline \multirow[t]{3}{*}{ Absorption } & 1.22 & 4.89 & 17. Pride & 0.747 \\
\hline & & & 22. Company Purposes/Focus & 0.568 \\
\hline & & & 11. Reputation & 0.518 \\
\hline
\end{tabular}


The results of factor analysis show there are six factors that can make Millennial employees engaged with their company (eigenvalue> 1). . A loading value of less than 0.50 according to Suliyanto [16] is considered not to have a meaningful role on the factors formed so that these variables can be ignored in the formation of factors. The loading value shows the magnitude of the correlation between the variables and the latent construct (factor). The data in the table shows that the number of variants that can be explained by factor 1 is 28.53 percent, factor 2 is 8.83 percent, factor 4 is 7.71 percent, factor 5 is 5.45 percent, factor 6 is 4.23 percent, so a total of six factors can explain the variant of 59.91 percent. The first factor formed was named an organization. The customers variable is the engagement driver with the highest loading value of 0.86 so that it can be concluded that the customers have the highest correlation with the latent organization of 86 percent. The second factor is the factor that is given the name compensation and benefits. The pay variable has the highest loading value of 0.81 so that it can be concluded that pay has the highest correlation with compensation and benefits at 81 percent. The third factor formed is a factor named the work. The variable with the highest loading value on this factor is autonomy of 0.79 so it can be concluded that autonomy has the highest correlation to latent the work of 79 percent. The fourth factor that is formed is a factor named team work where co-workers or coworkers become variables with the highest loading value of 0.72 , which means co-workers have the highest correlation with latent team work by 72 percent. The fifth factor that is formed is a factor that is given the name pride where the sense of accomplishment becomes the variable that has the highest loading value of 0.78 , which means that the sense of accomplishment has the highest correlation with the latent pride of 78 percent. The last factor is named performance where innovation is a variable with the highest loading value of 0.71 , which means innovation has the highest correlation with latent performance of 71 percent.

Test the accuracy of the model of the factors formed is concluded by utilizing the reproduced correlation matrix table output (Appendix 10). Based on the output of the reproduced correlation matrix, information is obtained that there are 40 percent residuals above the diagonal line that changes. Thus, the model formed from factor analysis is stated to be good because only 40 percent of the residuals above the diagonal line change or less than 50 percent.

\section{c. Strategy for Increasing Millennial Employee Engagement}

Based on the results of the analysis carried out, efforts are needed to improve the engagement of the Millennial employees. Increased engagement is done to get a positive impact on the high level of engagement of Millennial employees. Managerial implications in this study are presented through a tree diagram model as an approach used to identify the causes and consequences of a problem [18]. The compilation of tree diagrams in this study was formulated to develop logical steps in order to achieve a goal of increasing the engagement of Millennial employees in LQ 45 samples. Factor analysis resulted in six factors that could make Millennial employees engaged in their company. The strategy for increasing the engagement of Millennial employees in LQ 45 companies is presented using the tree diagram model as shown in Figure 5. 


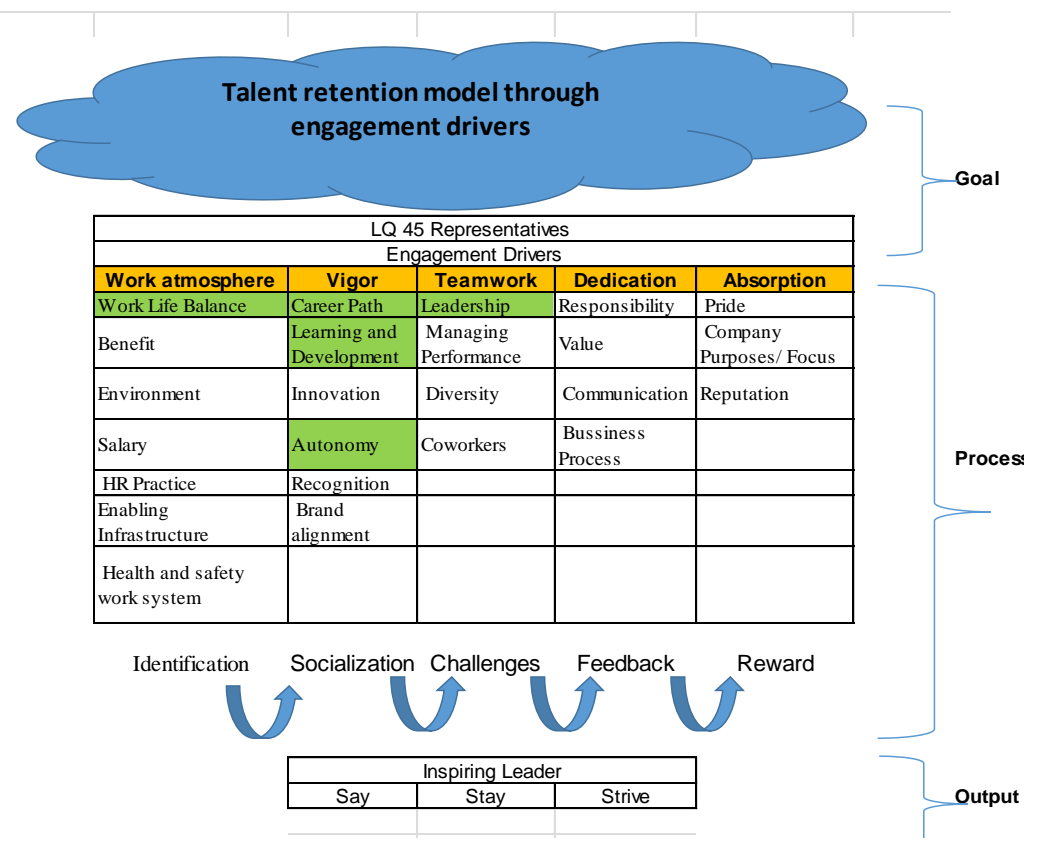

Fig. 5. Tree diagram of increased engagement with Millennial employees

The action plan for increasing the engagement of Millennial employees in LQ 45 companies recommended in this study is based on priority driver engagement according to Millennial employees and experts. Engagement drivers in question are work life balance, career opportunity, and autonomy. The strategy to increase engagement through engagement drivers is realized through the Co-Auto Balance Gamification formula, namely increasing engagement by utilizing the gamification system applied to Millennial employees. Gamification means implementing game elements into non-game contexts such as work in an organization with the aim of attracting users and resolving problems [19]. Gamification is not just a game with entertainment value. Gamification means entering game elements into existing processes to increase productivity, improve expertise and drive performance so as to increase employee engagement [18] An example of a company that applies gamification is Spotify, an online music streaming application company that has replaced the annual review system with a mobile gamified solution that is able to attract 90 percent employee participation even though the program is voluntary.

Implementing a gamification system through work life balance, career opportunity, and autonomy can be done by designing a game platform that is able to provide greater autonomy, freedom and independence for Millennial employees in doing their jobs while providing a balance between personal and work life and providing opportunities career growth. The gamification application scheme for Millennial employees in LQ 45 companies as shown in the model begins with identification, socialization, challenges, giving feedback, and giving rewards.

The first stage that can be done by the company in implementing this gamification is identification of work tasks that are suitable for gamification and in accordance with the objectives of the company. Next is to socialize the game platform and game elements that will be applied to the process so that employees (end users) can understand the gamification system. This socialization will be more effective if it is realized through a training program. After the employee is ready to use the gamification platform, the employee is given output-based daily, weekly, or 
monthly challenges that are continually updated after the completion of the task. Companies must give freedom to employees in solving these challenges based on creativity and personal initiative (autonomy). The platform should provide task completion instructions and problem solving scenarios for problems that are regular and predictable as recommendations for decision making. This is to ensure that input from management remains available so that the opportunity to make mistakes can be minimized. In addition, the completion of work assignments in the form of challenges can also be done with a virtual working mechanism that enables employees to work without the need to enter the office. This virtual working mechanism will provide more opportunities for Millennial employees with their families and take care of other interests without disrupting their productivity (work life balance).

Management can provide regular feedback for each work completed in the form of the challenge. The form of feedback that can be given in the form of points, increasing the level of challenges, as well as providing recognition (recognition) by utilizing game elements in the form of a badge (rank) for employees with the completion of the best tasks. These achievements besides being displayed on the game platform are also posted on the office social media group. Millennials really like to compare with each other because of the internet of things so this method will trigger employees to continue to solve the challenges given. This makes work feel more fun because of the motivation to solve challenges as when someone plays the game. Employees who are able to collect the most badges are given additional bonus incentives, vacation packages, or long-term rewards in the form of career opportunities.

This strategy is expected to make employees feel more entertained and motivated to complete tasks so as to make employees achieve the conditions of say, stay, and strive. Say means employees will always talk positively about their company to consumers, family, colleagues, and prospective employees who want to work in the same company so that indirectly employees become corporate image promotion agents without the need to incur additional costs. Stay means employees will feel comfortable and want to stay working at the company. Strive means employees have felt part of the company so they are strongly motivated to succeed the company.

\section{Conclusion}

Autonomy and career opportunity are the main engagement drivers of Millennial employees according to expert perceptions. The results of factor analysis show that there are six main factors that cause the Millennial Talent in representatives of LQ 45 companies to be engagewith their company. These factors are Vigor, Dedication, absorptions, Teamwork and ,work atmosphere.

The strategy undertaken to increase the level of Millennial Talent engagement is realized through a tree diagram model based on primary engagement drivers according to Millennial employee perceptions and expert perceptions. Work life balanced, Learning and development, leadership, autonomy, and career opportunity are the main engagement drivers used for strategy formulation based on Millennial employee perceptions and expert perceptions. The strategy formulation should involving inspiring leader to increase the engagement of Millennial employees/talents

\section{References}

[1] A. Hewitt, Trends in Global Employee Engagement :Making Engagement Happen[Internet]. [Diunduh 3 Januari 2017] tersediapada. 2015.

[2] A. Hewitt, Trends in Global Employee Engagement :Making Engagement Happen[internet]. [Diunduh 3 Januari 2017] tersediapada. 2016. 
[3] Deloitte, The 2016 Deloitte Millennial Survey [Internet]. [diunduh 31 Agustus 2018]. Tersedia pada. 2016.

[4] H. N. dan Strauss W, Millennials rising. New York: Vintage Books, 2000.

[5] D. N. dan Ramirez, "Cutting Through the Noise: The Right Employee Engagement Strategies for," YOU. Association for Talent Development, 2014.

[6] T. R. Clark, The Employee Engagement Mindset. USA: McGraw-Hill, 2012.

[7] P. L. Marciano, Carrots and Sticks Don't Work : Build A Culture of Employee Engagement with the Principles Of RESPECT. USA: McGraw-Hill, 2010.

[8] C. Andres, "Large Shareholders and Firm Performance - An Empirical Examination of Founding-Family Ownership,” Journal of Corporate Finance, vol. 14, 2008.

[9] Sugiyono, MetodePenelitianBisnis. Bandung (ID: PT Alfabeta, 2012.

[10] S. Lemmeshow, H. DW., K. J., and S. K. dan Lwanga, "Adequacy of Sample Size in," Health Studies. World Health, 1990.

[11] A. Bryman, Social Research Methods, 4th ed. New York (USA: Oxford University Press Inc, 2012.

[12] T. Donaldson and L. E. Preston, "Stakeholder theory of the corporation: concepts, evidence, and implications," Academy of Management, vol. 20, no. 1, pp. 65-91, 1995.

[13] H. Umar, MetodePenelitian untuk Skripsi dan TesisBisnis. Jakarta (ID: PT Raja, 2011.

[14] SiregarS, StatistikaDeskriptif untuk Penelitian. Cetakankedua. Jakarta: Rajawali Pers, 2011.

[15] B. Simamora, Analisis Multivariat Pemasaran. Jakarta (ID: PT Gramedia Pustaka Utama, 2005.

[16] Suliyanto, Analisis Data dalam Aplikasi Pemasaran. Bogor (ID: Ghalia Indonesia, 2005.

[17] D. J. E. dan Cowin L, "Multigenerational nurses in the workplace," Journal of Nursing Administration, vol. 34, no. 11, pp. 493-501, 2004.

[18] S. N. Silverman and dan N. L, Using Total Quality Tools for Marketing Research: A Qualitative Approach for Collecting Organizing, and Analyzing Verbal Response Data. [Internet]. [diunduh pada 9Agustus2017]. Tersedia pada. 1994.

[19] T. J. Brigham, "An introduction to gamification: Adding game elements for engagement. Medical Reference Services," Quarterly, vol. 34, no. 4, pp. 471-480, 2015. 